\title{
New data on the mineralogy of the salt deposit from Slănic Prahova (Romania)
}

\author{
Nicolae HAR ${ }^{*}$, Ovidiu BARBU ${ }^{2}$, Vlad CODREA ${ }^{2} \&$ Iustinian PETRESCU ${ }^{3}$ \\ ${ }^{1}$ Department of Mineralogy, "Babeş-Bolyai” University, 1 Kogălniceanu, 400084 Cluj Napoca, Romania \\ ${ }^{2}$ Department of Geology, "Babeş-Bolyai” University, 1 Kogălniceanu, 400084 Cluj Napoca, Romania \\ ${ }^{3}$ Department of Life and Earth Sciences, "Babeş-Bolyai” University, 4 Ştefan cel Mare, 400192 Cluj Napoca, Romania
}

Received January 2005; accepted March 2006

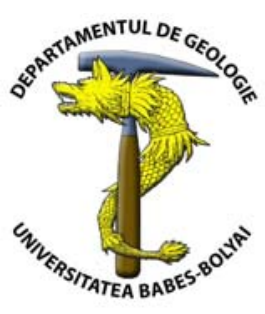

\begin{abstract}
The middle Badenian Ocnele Mari evaporitic formation from Slănic Prahova represents one of the most important salt deposits from the outer Carpathians (Prahova district). The salt deposit is located in the sedimentary succession of the Slanic syncline belonging to the post-tectogenetic cover of Tarcău Nappe. The sedimentary environment of the Ocnele Mari Formation was dominated by evaporitic condition covering the interval from the last stage of carbonates precipitation to halite, however, without reaching the stage of $\mathrm{K}$ and $\mathrm{Mg}$ salt precipitation. During evaporitic condition, authigenic minerals precipitated: carbonates, sulfates (anhydrite, gypsum and polyhalite) and halite (predominant). Simultaneously with the precipitation processes, an important input of sediments from the adjacent areas into the basin took place. Thus, minerals of allogenic origin (quartz, plagioclase feldspars, and clay minerals) are also present, sometime as interbedded layers in the salt formation.
\end{abstract}

Key words: salt deposit, halite, sulfates, allogenic minerals, Slănic Prahova, Romania

\section{INTRODUCTION}

The geological evolution of Romania passed over several saline events. The oldest known is late Paleozoic (Permian), known as "Cartojani horizon" (Paraschiv, 1981) and the most recent is middle Badenian (i.e., Wieliczian, which includes several formations, as Ocna Dej, Ocnele Mari or Cheia). This last one is also the most important due to its economic value, bearing the largest amounts and providing the best quality of salt. That explains why most of the salt mines of our country exploit only middle Miocene salt. The Badenian salt from Romania had known a long exploitation, beginning with the first human settlements into this area. Large quantities have been mined during the Roman conquest and in the Middle Age, continuing later in modern times. As a matter of fact, most salt sites from outer or inner Carpathian areas still preserve the traces of these old mining works. For the Badenian salt, several deposition patterns have been proposed over the last decades. Among them, those by Paucă $(1967,1968,1978)$ and Balintoni and Petrescu (2002), tried to explain the salt deposition due to the peculiar middle Miocene paleogeography and eustatic movements.

The attention of most geologists focused on the salt tectonics, stratigraphy, palinology, etc., whereas the Badenian salt mineralogy remained very little investigated. Among these few contributions, one can mention in the last years only the announcement of the presence of the glauberite at Ocnele Mari, near Râmnicu Vâlcea (Rebrişoreanu et al., 2005). Few and general studies regarding the mineralogy of salt deposit from Slănic Prahova can be also noticed. Ghiurcă and Drăgănescu
(1992) especially investigated the stratigraphy of the salt horizon as well as its bedrock and cover, and provided also some mineralogical data. Their study emphases on the mineralogy of the marls intercalations and recorded the presence of some groups of minerals (oxides, sulfides, carbonates and sulfates). They also identified the presence of authigenic silica precipitated from sub-saturated solution into a less rich sulfates ions environment.

As a consequence of new projects (SALRISC, SALSTRESS) betaken to the Miocene salt deposits from Romania, in the last years some salt sites were sampled in order to obtain additional data on geotechnics, mineralogy or mining improvements. One of these sites is Slănic, a famous salt mine with a long mining history.

\section{GEOLOGICAL FRAMEWORK}

Slănic is located in the outer Carpathians area (Prahova County), $45 \mathrm{~km}$ NE of Ploieşti. From a geological point of view, this locality belongs to the post-tectogenetic cover of Tarcău Nappe (Fig. 1). This nappe belongs to the Moldavides (Săndulescu, 1994) and is among the most important ones cropping out in the Eastern Carpathians. It includes Cretaceous, Paleogene and lower Miocene sedimentary successions (Săndulescu, 1984). Towards Prahova County, this nappe ends on two main anticlines, Homorâci and Văleni, separate by two synclines, Slănic and Drajna, both filled with Miocene molasse. The posttectogenetic sedimentary cover of Tarcău Nappe begun to accumulate in early Miocene ("Doftana Molasse") and ended in Sarmatian (Marinescu et al., 1998). 

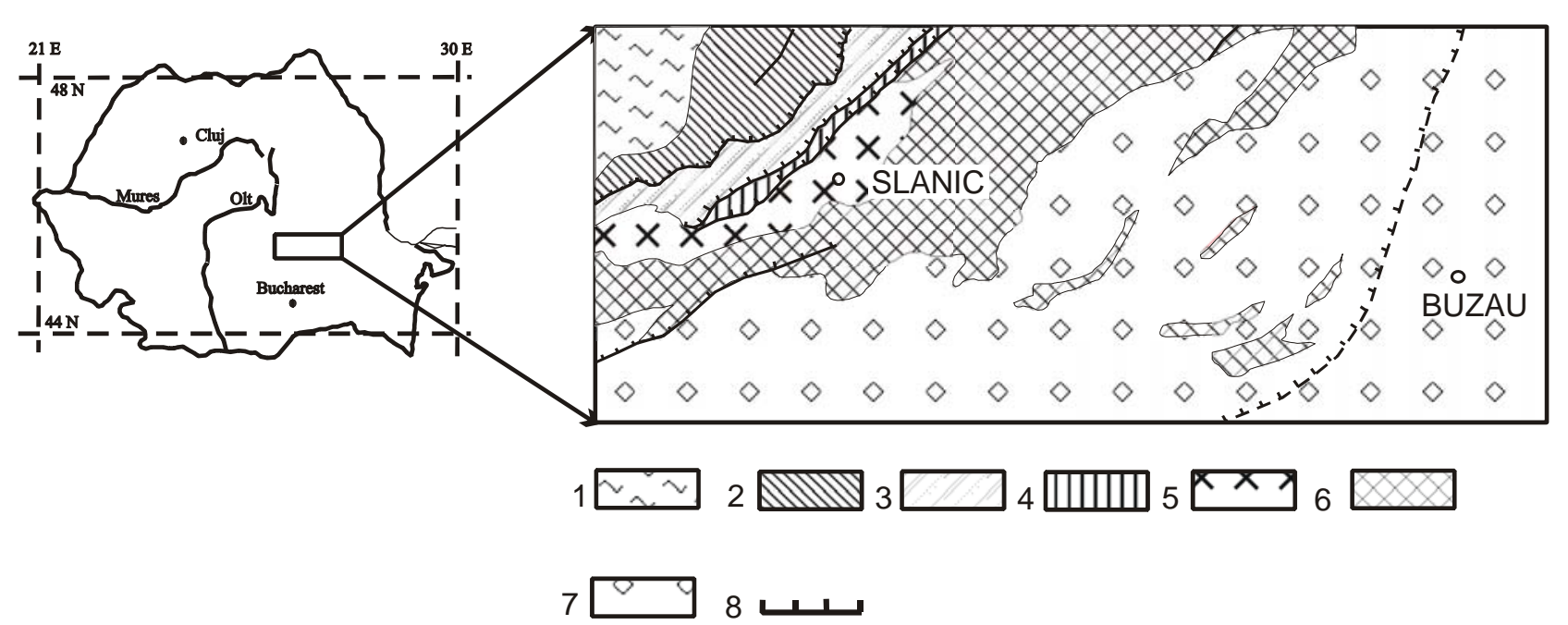

Fig. 1. Geology of Slănic area (after Săndulescu et al., 1995, modified). 1: Ceahlău Nappe; 2: Bobu Nappe; 3: Convolute flysch; 4: Macla Nappe; 5: Tarcău Nappe; 6: Subcarpathian Nappe; 7: Post-tectogenetic cover of Moldavides; 8: Foredeep.

In this area of the Tarcău Nappe, two evaporitic events took place. The first one is early Miocene in age and involves precipitation of mainly gypsum (Breaza Gypsum Member, part of Cornu Formation, Burdigalian). The second one is middle Miocene and developed in Badenian.

The Badenian succession begun with dacitic cinerites (tuffites) interbedded with carbonate clay rich in foraminifers, the Slănic Formation (early Badenian; formerly known as "Globigerina marls"). This formation is cropping in Slănic syncline at Piatra Verde, not far from Slănic town.

An evaporitic formation follows this episode, which involves concurrently salt and gypsum, related to Ocnele Mari Formation (middle Badenian, i.e., Wieliczian). This salt is mined at Slănic, in the Victoria salt mine ("Cantacuzino" field). Before "70s, the mining works were carried on in Unirea mine, nowadays a show salt mine.

The salt is covered by the Drajna Formation (late Badenian, i.e., Kosovian), comprises the deposits formerly known as "Radiolarian Shales" and "Spirialis Marls", siltic clays, argillites and sands, sometimes with sandstone and a thin gypsum level interbedded (Săndulescu et al., 1995). Radiolarians and extremely numerous Limacina species are the dominant fossils of this formation.

The Slănic syncline appears as a normal fold, pitching to NW, with asymmetric flanks: the SE one is sharply inclined, opposed to the NW one. At the west of Valea Mare, the Slănic syncline is folded and reversed towards SE. The whole syncline is fragmented by longitudinal and transverse faults. Its central part has some secondary folds, affected by faults.

The salt appears as a lens-like accumulation, with widest thickness in its central area (499 m). In the central-north area, there is a small diapiric tendency, due to the lateral pressure developed by the Homorâci anticline. Here, the salt deposit is penetrating the overlying Badenian deposits.

\section{SAMPLING AND ANALYTICAL TECHNIQUES}

The samples we analyzed originate from "Cantacuzino" mine, and were collected in 2004. In order to identify the mineralogical assemblages of salt deposit from Slănic Prahova, different methods of samples preparation and subsequent analytical techniques were used. Thin sections made on natural samples were investigated under polarizing microscope in order to study especially the anisotropic minerals (sulfates, carbonates, etc.) and their spatial relationship with the main mineral constituent represented by halite. X-ray powder diffractions (XRD) using a Dron - 3 diffractometer $\left(2 \theta=4-64^{\circ}\right)$ were also performed on natural samples as well as on the detrital material extracted from salt samples. For the identification of clay minerals the XRD were also performed on water treated (orientated) samples.

\section{MINERALOGY OF SALT DEPOSIT}

Salt looks like crystal aggregate and as gritty mass in the salt body, one can observe white, gray and blackish salt strata, folded and interbedded (Fig. 2). The grey or blackish salt has smaller crystals as compared to the white one. The general aspect of this deposit is a variegated one. The color change reflects turnovers that took place in the precipitation process, due to the climatic variations and changes in sedimentary input into the sedimentary basin. The mining works evidenced laminations of the salt body towards its margins.

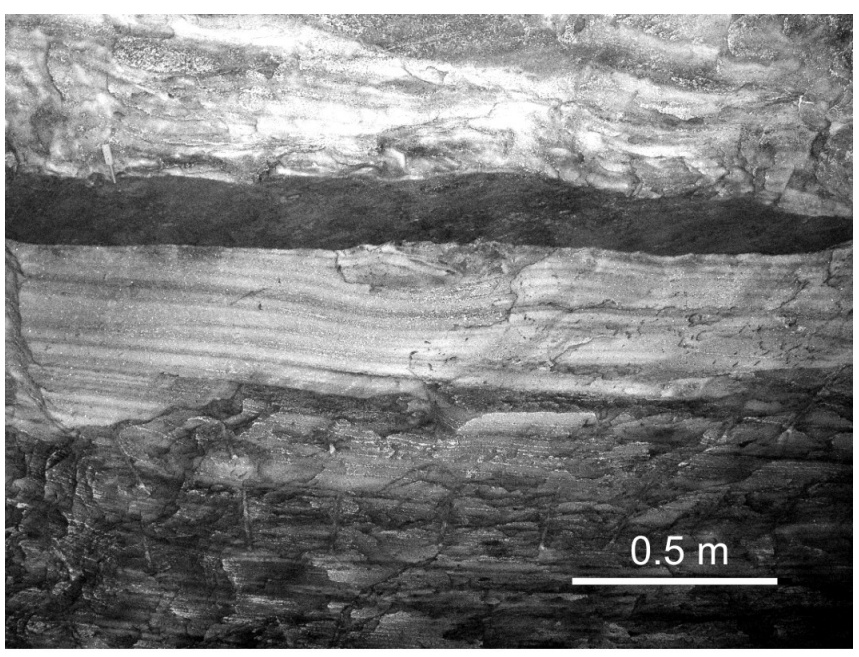

Fig. 2. White and dark-grey interbedded strata in the salt deposit from Slănic Prahova. 
Two different genetic types of minerals are present in the salt deposit from Slănic Prahova:

- Authigenic minerals, genetically related to the precipitation processes into the sedimentary basin under evaporitic conditions: halite (which is the most abundant mineral - $95 \mathrm{wt} \%$ ), anhydrite, gypsum, polyhalite, and dolomite;

- Allogenic minerals resulted due to the sedimentary input in the basin: quartz, feldspars, muscovite, clay minerals etc.

Halite (NaCl) is the most abundant authigenic mineral. The size of cubic crystals of halite are up to $2 \mathrm{~cm}$ and under the microscope is colorless and optically isotropic, with cubic cleavage (Plate I, A). It is usually associated with sulfates as anhydrite, gypsum and polyhalite. Sometimes the associated sulfates are developed on the cleavage planes of halite, suggesting the diagenetic genesis of some of them (Plate I, B). The X-ray diffraction on natural samples (Fig. 3) reveals the most common peaks of halite, defined by the following $\mathrm{d}(\AA) / \mathrm{I}$ values: $3.23 / 15 ; 2.82 / 100 ; 1.99 / 50$; $1.70 / 5$ and $1.62 / 15$.

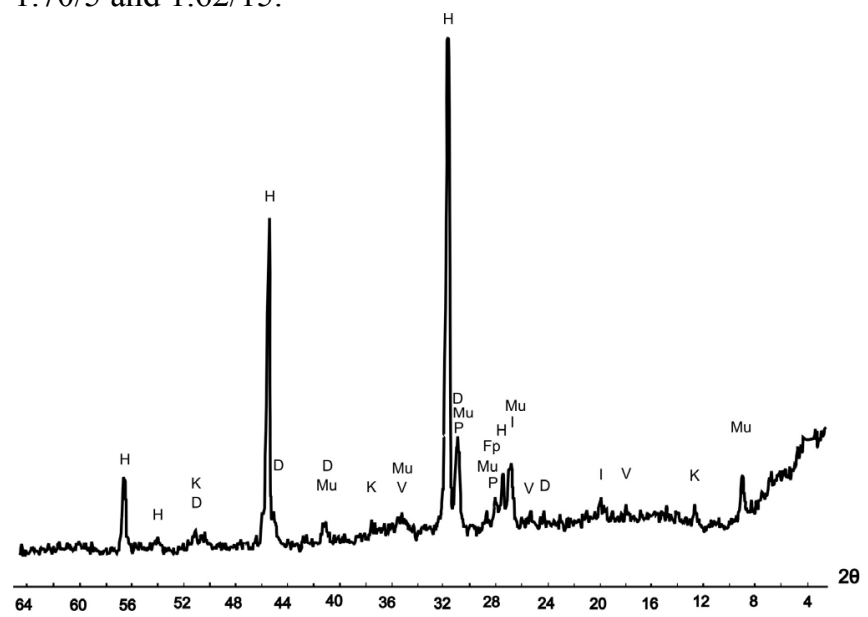

Fig. 3. The XRD patterns of natural sample of salt from Slănic Prahova. H - Halite; D - Dolomite: Mu - Muscovite; $P$-Polyhalite, $K$-Kaolinite, $I$-Illite; $V$-Vermiculite; Fp-Feldspars.

The sulfates, represented by anhydrite, gypsum, and polyhalite, are an important group of authigenic minerals associated with halite. They are developed as granular masses as well as nests and isolated tabular crystals among halite crystals (Plate I, C) or, in some cases, they represent the cement of the brecciated salt.

Anhydrite $\left(\mathrm{CaSO}_{4}\right)$ is the most abundant sulfate associated with halite, gypsum, and polyhalite. It occurs as isolated or nests of tabular crystals as well as granular masses. Under the microscope, anhydrite shows typical tabular, colorless crystals with cleavage at right angles (Plate I, E and F) and right extinction. It has typical high and zoned colors of birefringence. The anhydrite crystals are variable in size, the largest being of $0.10 / 0.80 \mathrm{~mm}$.

XRD of detrital compounds extracted from salt samples, by dissolving halite in distilled water were also performed. The $\mathrm{d}(\AA) / \mathrm{I}$ patterns of anhydrite are (Fig. 4$): 3.47 / 100 ; 3.11 /$ $90 ; 2.84 / 3 ; 2.31 / 10 ; 2.19 / 20 ; 2.08 / 10 ; 1.86 / 15 ; 1.74 / 10$ and $1.64 / 15$.

Gypsum $\left(\mathrm{CaSO}_{4} \cdot \mathbf{2 H}_{2} \mathrm{O}\right)$ was identified under the microscope. It forms tabular crystals or granular masses with lower birefringence as compared with anhydrite. The gypsum is colorless and, in cross-polarized light show symmetrical extinction.

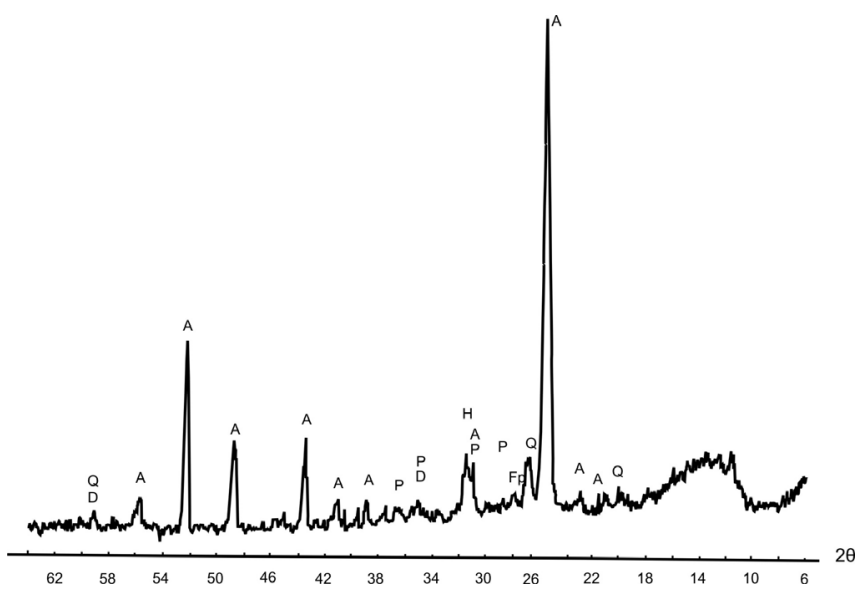

Fig. 4. The XRD patterns of detrital compounds of salt from Slănic Prahova. A-anhydrite, $Q$-quartz, $H$-halite, $D$-dolomite $P$-polyhalite, $F p$-feldspars.

Polyhalite $\left(\mathrm{K}_{2} \mathrm{CaMg}\left[\mathrm{SO}_{4}\right]_{4} \mathbf{2 H}_{2} \mathrm{O}\right)$ occurs as granular masses and fibrous crystals and under the microscope shows low birefringence. Using XRD, the following $\mathrm{d}(\AA) / \mathrm{I}$ lines of polyhalite were identified: $3.19 / 100 ; 2.92 / 25 ; 2.84 / 20$; 2.55/10 and 2.45/5 (Figs. 3 and 4).

Dolomite $\left.\left(\mathrm{CaMg}_{\mathrm{C}} \mathrm{CO}_{3}\right]_{2}\right)$ is also present as authigenic mineral and was identified as isolated rhombohedral crystals with typical slightly curved faces, included in halite (Plate I, D). Using XRD on a natural sample (Fig. 3) as well as on detrital samples extracted from salt (Fig. 4) and on water oriented/treated samples (Fig. 5), the most representative peaks of dolomite were found at the following $\mathrm{d}(\AA) / \mathrm{I}$ : $3,68 / 10 ; 2,88 / 100 ; 2.55 / 20 ; 2,18 / 20 ; 2.01 / 10$ and $1.85 / 10$.

Quartz $\left(\mathrm{SiO}_{2}\right)$ is one of the most important minerals of allogenic origin and was identified using XRD performed on detrital extracts from salt samples as well as on natural ones.

It is present as the trigonal variety having the strongest lines at $\mathrm{d}(\AA) / \mathrm{I}: 4.26 / 40 ; 3.34 / 100 ; 2.45 / 10 ; 2.20 / 10$ and 1.80/10 (Fig. 5)

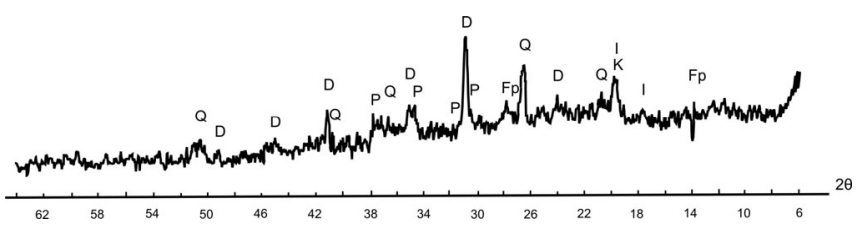

Fig. 5. The XRD patterns of water-treated (oriented) material extracted from salt samples. $D$-dolomite; $Q$-quartz; Fp-feldspar, $K$-kaolinite; $I$-illite, $P$-polyhalite.

Plagioclase feldspars $\left(\mathrm{NaSi}_{3} \mathrm{AlO}_{\mathbf{8}}-\mathrm{CaSi}_{2} \mathrm{Al}_{2} \mathrm{O}_{\mathbf{8}}\right)$ are also present in the mineralogical assemblage of allogenic minerals. Only a few typical peaks characteristic to plagioclase were identified on the XRD analyses performed on natural sample of salt as well as on water-treated material extracted from salt samples. The $\mathrm{d}(\AA)$ values are 6.34 and $3.19-3.20$ (Figs 3 and 5).

Clay minerals assemblages in salt formation from Slănic Prahova consist of kaolinite, illite and vermiculite. They were identified using $\mathrm{X}$ - ray diffraction performed on natural sample and on water treated material extracted from salt. They are defined by the following $\mathrm{d}(\AA)$ values (Figs. 3 and 5): 7.13 (kaolinite); 4.97 and 4.43 (illite); 4.54 and 4.48 (vermiculite), 4.33 (kaolinite); 3.60 (kaolinite); 2.55 (vermiculite), 2.40 (illite); 2.39 (vermiculite). 


\section{CONCLUSION AND GENETIC CONSIDERATIONS}

Beginning with middle Badenian, the paleogeographic changes that took place in the Slănic region led to a restrictive sedimentary basin and the precipitation of Ocnele Mari Formation begun. Little amounts of carbonates mostly represented by calcite were quickly transformed into dolomite as a result of diagenesis, being the first products of precipitation (Fig. 6). Dolomite is present as isolated and typical rhombohedral crystal included by halite.

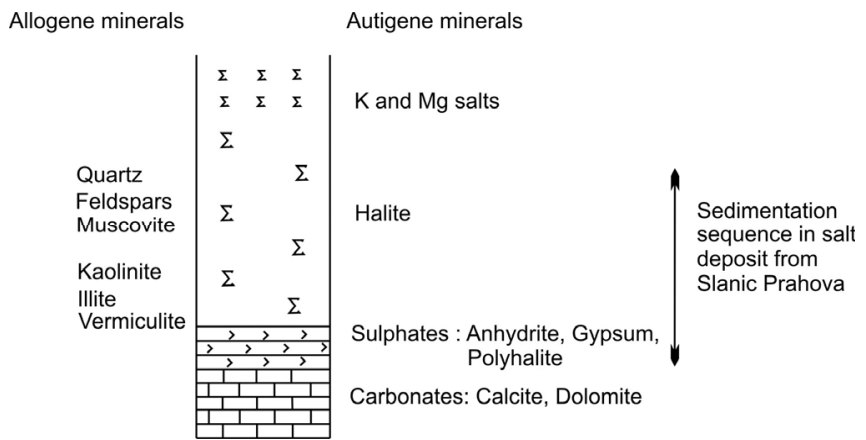

Fig. 6. Sedimentation sequence and the main mineralogical features of the salt deposit from Slănic Prahova.

Sulfates represented by anhydrite, gypsum and polyhalite were the next authigenic minerals precipitated into the basin. Isolated or nests of tabular and prismatic crystals along with granular masses are the common habits of sulfates. The presence of some sulfates on the cleavage planes of halite also suggests their diagenetic genesis. Halite is the last and the main authigenic mineral precipitated into the sedimentary basin. The early formed authigenic minerals are included by halite. Halite included also allogenic minerals (quartz, feldspars, and clay minerals) of whose origin is in the adjacent areas. The episodic input of the allogenic minerals into the basin is consistent with the presence of dark-color interbedded strata in the salt deposit from Slănic Prahova. The sedimentary sequence of the salt deposit from Slănic Prahova covers the interval from the last stage of carbonates precipitation to halite, without reaching the episode of $\mathrm{K}$ and $\mathrm{Mg}$ salt precipitation.

\section{R E F E R E N C E S}

Balintoni, I., Petrescu, I. 2002, A hypothesis on the Transylvanian halite genesis. Studia Universitatis „Babeş-Bolyai”, Geologia, Special issue 1: 51-61.

Ghiurcă, N., Drăgănescu, L. 1992, A few geological data on the salt massive at Slănic Prahova. Studia Universitatis "Babeş-Bolyai", Geologia, 37 (1): 53 - 56.

Marinescu, F., Mărunțeanu, M., Papaianopol, I. \& Popescu, G. 1998, Tables with the correlation of the Neogene deposits in Romania. Romanian Journal of Stratigraphy, 78: 181-186.

Paucă, M. 1967, Contribuții la geneza zăcămintelor de săruri miocene din România. Dări de Seamă ale Institutului Geologic, LIII (2) (1965-1966): 159-184.

Paucă, M. 1968, Problema genezei evaporitelor din România. Progresele Ştiinței, 4 (10): 454-459.

Paucă, M. 1978, Evaporitele din România. Aspecte genetice, paleogeografice şi tectonice. Anuarul Muzeului de Științe Naturale Piatra Neamț, Seria Geol.-Geogr., IV: 7-47.

Rebrişoreanu, M., Postolache, M., Danciu, C. \& Lorincz, C. 2005, Considerații structo-texturale privind influența factorului tectonic şi a condiților de exploatare asupra masivului de sare Coceneşti. Universitaria SIMPRO 2005, Fascicula Inginerie geologică, civilă şi industrială: 71-73.

Săndulescu, M. 1984, Geotectonica României. Editura Tehnică, București, 336 pp.

Săndulescu, M. 1994, Overview on Romanian geology. ALCAPA II, Geological evolution of the AlpineCarpathian-Pannonian system. Romanian Journal of Tectonics and Regional Geology, 75 (Suppl. 2): 3-15.

Săndulescu, M., Popescu, G. \& Mărunțeanu, M. 1995, Facies and stratigraphy of the Lower and Middle Miocene formations of the Slănic Syncline. Romanian Journal of Stratigraphy, 76 (Suppl. 6): 3-11. 


\section{Plate I}
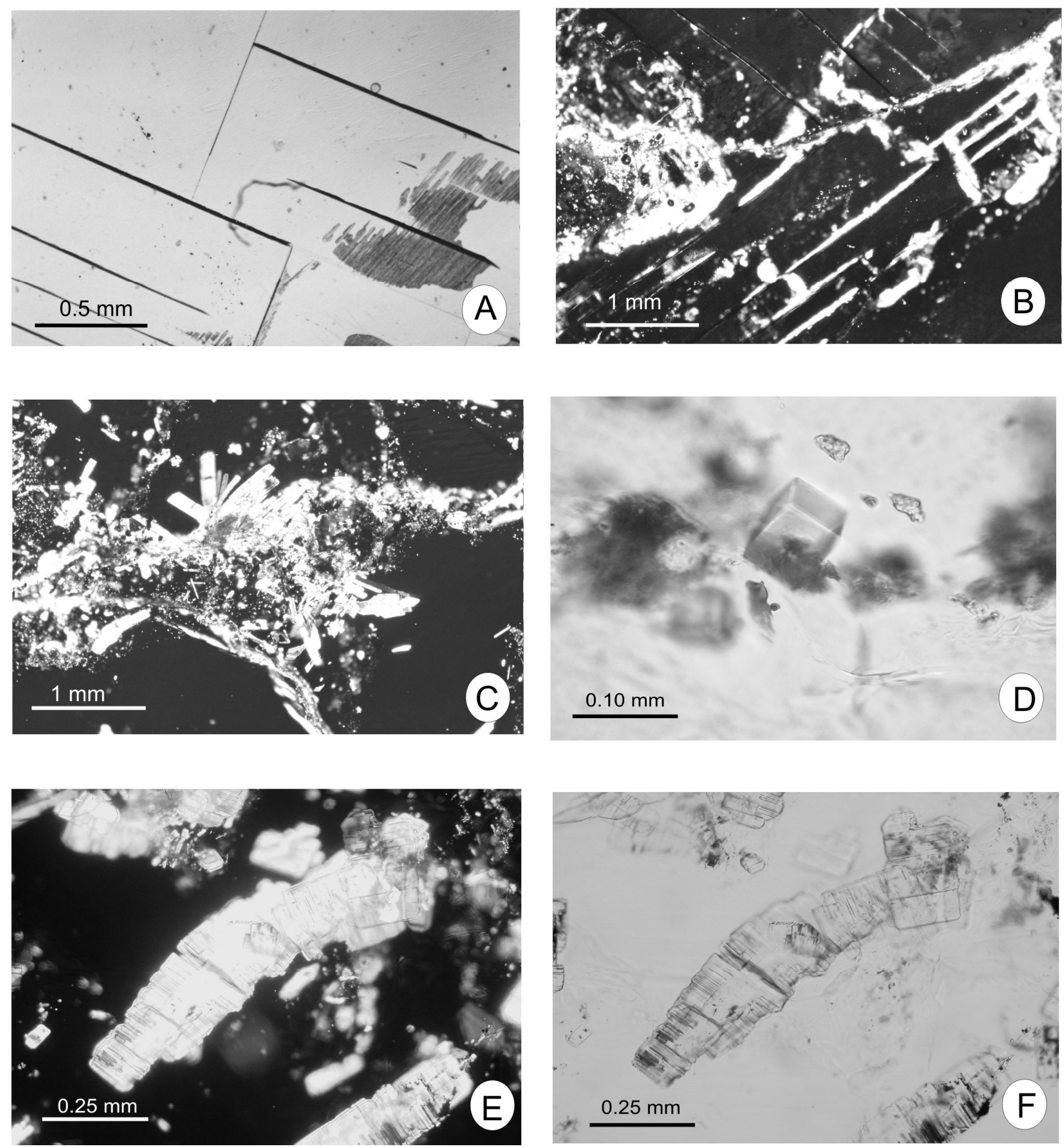

Plate I

A. Microphotograph of colorless crystal of halite with cubic cleavage seen in plain light.

B. Cross-polarized light microphotograph of isotropic halite and associated sulfates and clay minerals.

C. Cross-polarized image showing granular masses and nests of tabular crystals of sulfates within isotropic halite.

D. Isolated rhombohedral crystal of dolomite included in halite.

E - F. Tabular crystals of anhydrite with cleavage at right angles (coss-polarized nicols $(E)$ and parallel nicols $(F)$ ). 